\title{
HUBUNGAN ASUPAN PROTEIN DAN LEMAK DENGAN STATUS KESEHATAN MULUT ANAK USIA PRASEKOLAH DI KECAMATAN JETIS KABUPATEN BANTUL D.I. YOGYAKARTA
}

\author{
Jatri Handijani ${ }^{1}$, Al Supartinah², R. Dwi Budiningsari ${ }^{3}$
}

\begin{abstract}
Background: The main problem of children's oral cavity are caries and gingivitis. One cause of caries and gingivitis is plaque of which its formation and composition are affected by nutritional factor. Nutrition can be cariogenic or non cariogenic both of which can bring direct or indirect impact to oral cavity. In the oral cavity both protein and fat are non cariogenic.

Objective: To identify the relationship between protein and fat intake with oral health status (level of caries seriousness, oral cleanliness, gingiva health and saliva acidity) of preschool children in Jetis subdistrict, Bantul District, Yogyakarta Special Territory.

Methods: This was an observational study which used a cross sectional design. Subject of study were 100 children of 4-6 years old taken by using propotional random sampling. Data collected consisted of eating pattern, respondent characteristics, level of caries seriousness, oral cleanliness, gingiva health and saliva acidity. Data analysis used Person correlation statistic and linier regression. Data collected consisted of eating pattern, respondent characteristics, level of caries seriousness, oral cleanliness, gingival health status and saliva acidity. Data analysis used Pearson correlation statistic and linear regression tests.

Results: Result of the study showed that there was relationship between protein and fat intake with oral cleanliness and saliva acidity $(p<0.05)$ and there was no relationship between protein and fat intake with level of caries seriousness and gingiva health $(p>0.05)$

Conclusion: There was relationship between protein and fat intake with oral health status (oral cleanliness and saliva acidity), but not with oral health status (level of caries seriousness and gingiva health).
\end{abstract}

Key words : Intake of protein and fat, oral health status, preschool children.

\section{PENDAHULUAN}

Masalah utama dalam rongga mulut anak adalah karies gigi, dan kemudian gingivitis. Telah banyak usaha yang dilakukan untuk menurunkan prevalensi karies namun dirasa kurang berhasil, terbukti masih tingginya prevalensi penyakit tersebut (1).

Penelitian di 100 TK Kodya Yogyakarta, didapatkan prevalensi karies sebesar $85 \%$ dan gingivitis $82 \%$ (2). Penelitian di daerah Kalasan Yogyakarta didapatkan prevalensi karies anak-anak TK sebesar $93,3 \%$ dan gin- givitis sebesar $48,89 \%$ dan di salah satu TK daerah Godean Yogyakarta, prevalensi karies sebesar 95,9\% dan gingivitis sebesar $47,3 \%$ (3).

Di dalam rongga mulut makanan mempunyai 2 efek yaitu efek lokal dan sistemik. Efek lokal yaitu sifat makanan sebagai pembersih, yang berperan di sini adalah makanan yang mengandung serat. Efek sistemik yaitu melalui pencernaan makanan dan absorbsi nutrien dalam makanan yang dapat berpengaruh pada gigi, sebelum dan sesudah erupsi. Kariogenisitas suatu makanan juga dipengaruhi oleh komposisi nutrien dalam makanan yang dikonsumsi sehari-hari (4). Protein bersifat nonkariogenik, karena meningkatkan kadar urea yang berfungsi sebagai penyangga di dalam saliva, dapat menekan penurunan $\mathrm{pH}$ saliva sehingga mencegah kondisi asam di dalam rongga mulut. Lemak dapat menurunkan aktivitas karies gigi dengan membentuk lapisan pada permukaan email sehingga mencegah perlekatan mikroorganisme. Makanan yang kariogenik dapat menumpuk di daerah servikal gigi. Bentuk makanan yang halus, lunak dan lengket sukar dibersihkan, sehingga gingivitis lebih mudah terjadi (5).

Untuk mengetahui status kesehatan mulut antara lain dengan mengukur kebersihan mulut berdasarkan plak pada permukaan gigi anak dengan menggunakan indeks PHP-M (Personal Hygiene Performance-Modified) (6), menghitung tingkat keparahan karies gigi dengan CSI (Caries Severity Index) (7), melihat ada atau tidak ada gingivitis dengan kriteria gingiva sehat dan gingivitis (8) serta mengetahui derajat keasaman saliva $(\mathrm{pH})$ dengan Saliva-Check Buffer.

Puskesmas Jetis Bantul dalam data Usaha Kesehatan Gigi Sekolah (UKGS) pada tahun 2003 mencatat prevalensi karies sebesar $96,2 \%$ dan gingivitis sebesar $53,7 \%$. Anak usia prasekolah tidak tercakup dalam UKGS dan perhatian pada Usaha Kesehatan Gigi Masyarakat Desa (UKGMD) di Kecamatan Jetis masih kurang.

Anak prasekolah merupakan salah satu kelompok rawan terhadap penyakit gigi dan mulut karena mempunyai perilaku atau kebiasaan diri yang kurang menunjang terhadap kesehatan gigi dan mulut (9).

\footnotetext{
${ }_{1}$ Puskesmas Rapak Balikpapan

${ }^{2}$ Fakultas Kedokteran Gigi UGM, Yogyakarta

${ }^{3}$ Magister Gizi dan Kesehatan UGM, Yogyakarta
} 
Frekuensi karies gigi sulung merupakan indikator kesehatan gigi anak usia prasekolah, sehingga perlu diperhatikan karena gigi sulung berfungsi memacu pertumbuhan rahang, memberi jalan dan tempat bagi gigi tetap penggantinya (10).

Tujuan umum penelitian ini untuk mengetahui hubungan antara asupan protein dan lemak dengan status kesehatan mulut pada anak usia prasekolah di Kecamatan Jetis Kabupaten Bantul Daerah Istimewa Yogyakarta. Tujuan khusus adalah untuk mengetahui asupan protein, asupan lemak, dan status kesehatan mulut pada anak usia prasekolah.

\section{BAHAN DAN METODE}

Jenis penelitian yang digunakan adalah penelitian observasi dengan menggunakan rancangan penelitian cross sectional (11).

Subjek penelitian adalah anak prasekolah TK PKK Turi (gugus 1), TK Kuncup Harapan Paten dan TKABA Denokkan (gugus 2) serta TK Tunas Harapan Balakan (gugus 3). Responden penelitian adalah orang tua/wali murid. Pengambilan sampel dilakukan secara propotional random sampling (11) dengan kriteria inklusi sebagai berikut: 1) Usia 4-6 tahun; 2) Sehat jasmani; 3) Bertempat tinggal di Kecamatan Jetis Kabupaten Bantul; 4) Kooperatif; 5) Bersedia menjadi subjek penelitian, dengan cara orang tua/wali murid menandatangani inform consent. Jumlah subjek penelitian ditetapkan dengan menggunakan rumus Lemeshow et al (12), maka jumlah subjek penelitian adalah 97 anak (minimal), dibulatkan menjadi 100 anak.

Penelitian dilakukan selama 3 bulan, yaitu mulai bulan Oktober sampai Desember tahun 2004. Data yang dikumpulkan meliputi data identitas subjek penelitian, karakteristik keluarga, asupan protein dan lemak, tingkat keparahan karies gigi, derajat kebersihan mulut, kesehatan gingiva dan derajat keasaman saliva. Data asupan protein dan lemak diperoleh dari recall $1 \times 24$ jam selama 4 hari (13).

Pengolahan data untuk asupan protein dan lemak dengan menggunakan Nutrisurvey. Analisis data untuk mengetahui hubungan antara variabel bebas (asupan protein dan lemak) dengan variabel terikat (status kesehatan mulut) digunakan uji statistik korelasi Pearson dan regresi linier.

\section{HASIL DAN BAHASAN}

\section{Gambaran Umum Lokasi Penelitian}

Kecamatan Jetis merupakan salah satu kecamatan di wilayah Kabupaten Bantul, Daerah Istimewa Yogyakarta dengan batas wilayah kecamatan, sebelah utara Kecamatan Sewon, timur Kecamatan Imogiri, selatan
Kecamatan Pundong dan barat Kecamatan Bantul. Wilayah Kecamatan Jetis terdiri 4 desa yaitu Desa Canden, Sumberagung, Trimulyo dan Patalan serta meliputi 64 dusun. Luas wilayah $3.759,65 \mathrm{Ha}$ dengan jumlah penduduk pada tahun 2003 sebesar 49.802 jiwa.

Wilayah Kecamatan Jetis mempunyai 27 TK yang terbagi dalam 3 gugus. Gugus 1 terdapat $10 \mathrm{TK}$, gugus 2 terdapat 9 TK, dan gugus 3 terdapat 8 TK. Lokasi penelitian dilakukan di TK PKK Turi (gugus 1), TK Kuncup Harapan Paten, dan TKABA Denokkan (gugus 2) serta TK Tunas Harapan Balakan (gugus 3).

\section{Karakteristik Keluarga}

Karakteristik keluarga meliputi pekerjaan dan pendidikan ayah serta ibu, disajikan pada Tabel 1. Proporsi terbesar pekerjaan ayah adalah buruh tani yaitu 32 orang (32\%) dan proporsi terendah sebanyak 4 orang $(4 \%)$ sebagai TNI/POLRI. Pekerjaan ibu adalah 52 orang (52\%) tidak bekerja (ibu rumah tangga) dan 5 orang (5\%) sebagai PNS. Pekerjaan akan berdampak pada penghasilan keluarga untuk memenuhi kebutuhan hidupnya.

Proporsi pendidikan ayah terbesar adalah Sekolah Menengah Atas sebanyak 43 orang (43\%) dan proporsi terendah adalah Perguruan Tinggi sebanyak 6 orang $(6 \%)$. Pendidikan ibu sebagai responden penelitian ini,

TABEL 1. Karakteristik keluarga

\begin{tabular}{|c|c|c|}
\hline Karakteristik & $\mathbf{n}$ & $\%$ \\
\hline \multicolumn{3}{|l|}{ Pekerjaan ayah } \\
\hline Tani & 25 & 25 \\
\hline Buruh Tani & 32 & 32 \\
\hline PNS & 10 & 10 \\
\hline TNI/POLRI & 4 & 4 \\
\hline Pedagang & 29 & 29 \\
\hline Jumlah & 100 & 100 \\
\hline \multicolumn{3}{|l|}{ Pekerjaan ibu } \\
\hline Buruh Tani & 32 & 32 \\
\hline PNS & 5 & 5 \\
\hline Pedagang & 11 & 11 \\
\hline Tidak Bekerja & 52 & 52 \\
\hline Jumlah & 100 & 100 \\
\hline \multicolumn{3}{|l|}{ Pendidikan ayah } \\
\hline SD & 21 & 21 \\
\hline SMP & 30 & 30 \\
\hline SMA & 43 & 43 \\
\hline PT & 6 & 6 \\
\hline Jumlah & 100 & 100 \\
\hline \multicolumn{3}{|l|}{ Pendidikan ibu } \\
\hline SD & 40 & 40 \\
\hline SMP & 43 & 43 \\
\hline SMA & 16 & 16 \\
\hline PT & 1 & 1 \\
\hline Jumlah & 100 & 100 \\
\hline
\end{tabular}


proporsi terbesar adalah Sekolah Menengah Pertama sebanyak 43 orang (43\%) dan proporsi terendah adalah Perguruan Tinggi sebanyak 1 orang (1\%). Pendidikan dapat mempengaruhi kemampuan seseorang dalam memahami informasi yang diperolehnya.

\section{Karakteristik Subjek Penelitian}

Karakteristik subjek penelitian dapat dilihat pada Tabel 2. Subjek penelitian rata-rata berumur 5 tahun, nilai CSI tidak parah; nilai PHP-M sedang; terdapat gingivitis; pH saliva sedang; asupan proteinnya lebih; asupan lemaknya kurang dan frekuensi menyikat gigi 2 kali sehari. diperkirakan sudah cukup melapisi permukaan gigi, sehingga sisa makanan tidak mudah menempel pada gigi.

\section{Asupan Protein dan Lemak dengan Status Kesehatan Mulut}

Pada Tabel 4 terlihat bahwa terdapat 35 anak dengan asupan protein lebih dan nilai PHP-M tinggi; 1 anak dengan asupan protein kurang dan nilai PHP-M rendah. Asupan lemak lebih dan nilai PHP-M tinggi terdapat pada 17 anak serta 1 anak dengan asupan lemak kurang dan nilai PHP-M rendah. Terdapat 7 anak dengan asupan protein lebih dan CSI parah; 17 anak dengan

TABEL 2. Karakteristik subjek penelitian

\begin{tabular}{lcccc}
\hline \multicolumn{1}{c}{ Variabel } & Min & Max & Mean & SD \\
\hline Umur anak (th) & 4,50 & 6,00 & 5,21 & 0,33 \\
CSI & 1,80 & 4,60 & 4,50 & 0,30 \\
PHP-M & 20,00 & 43,00 & 35,71 & 7,09 \\
Gingivitis & 1,00 & 2,00 & 1,70 & 0,46 \\
pH saliva & 5,60 & 6,80 & 5,96 & 0,29 \\
Frekuensi menyikat gigi & 1,00 & 3,00 & 2,13 & 0,46 \\
Asupan protein & 25,00 & 58,50 & 38,39 & 7,06 \\
Asupan lemak & 23,60 & 67,80 & 37,39 & 8,27 \\
\hline
\end{tabular}

\section{Asupan Protein dan Lemak}

Asupan protein dan lemak dihitung dari hasil recall 24 jam selama 4 hari. Hasil olah data dengan Nutrisurvey ini diperoleh rata-rata asupan protein dan lemak kemudian dikonversikan dengan Angka Kecukupan Gizi (AKG) (Tabel 3). asupan protein kurang dan CSI tidak parah. Asupan lemak lebih dengan CSI parah terdapat pada 4 anak serta 48 anak dengan asupan lemak kurang dan CSI tidak parah. Terdapat 57 anak dengan asupan protein lebih dan tidak ada gingivitis; 8 anak dengan asupan protein kurang dan ada gingivitis. Asupan lemak lebih dan tidak ada gingivitis terdapat

TABEL 3. Rata-rata asupan protein dan lemak

\begin{tabular}{cccccc}
\hline Variabel & AKG & Mean & SD & x AKG (\%) & SD (\%) \\
\hline Protein & $32(\mathrm{gr})$ & 38,39 & 7,067 & 119,95 & 22,06 \\
Lemak & $38(\mathrm{kkal})$ & 37,39 & 8,27 & 98,37 & 21,75 \\
\hline
\end{tabular}

Berdasarkan Tabel 3 diperoleh hasil bahwa protein sudah mencukupi dibanding rata-rata angka kecukupan gizi, sedangkan lemak masih kurang dibanding rata-rata angka kecukupan gizi.

Rata-rata asupan protein per hari pada subjek penelitian sudah mencukupi angka kecukupan gizi yang dianjurkan, yaitu 119,9 \% AKG. Makanan sehari-hari dan tersedia di pasaran yang merupakan sumber protein bagi subjek penelitian ini berasal dari nabati yaitu tahu, tempe, kacang panjang, bayam, adaun singkong, pisang, dan jeruk. Protein hewani sebagian diperoleh dari mengkonsumsi telur dan ikan lele.

Rata-rata asupan lemak pada penelitian ini kurang dari angka kecukupan gizi yaitu 98,37\% AKG, tetapi pada 33 anak serta 18 anak dengan asupan lemak kurang dan ada gingivitis. Terdapat 7 anak dengan asupan protein lebih dan $\mathrm{pH}$ saliva normal; 11 anak dengan asupan protein kurang dan $\mathrm{pH}$ saliva asam. Asupan lemak lebih dan $\mathrm{pH}$ saliva normal didapat pada 6 anak serta 30 anak dengan asupan lemak kurang dan $\mathrm{pH}$ saliva asam.

\section{Hubungan Asupan Protein dan Lemak dengan Sta- tus Kesehatan Mulut}

Hubungan asupan protein dan lemak dengan status kesehatan mulut dengan uji statistik koralasi Pearson dapat dilihat pada Tabel 5. Dari uji korelasi Pearson diperoleh bahwa antara asupan protein dan lemak berhubungan dengan PHP-M dan pH saliva. Namun pro- 
TABEL 4. Asupan protein dan lemak dengan PHP-M

\begin{tabular}{llcccccccccc}
\hline \multirow{2}{*}{ Asupan } & \multirow{2}{*}{ Kategori } & \multicolumn{3}{c}{ PHP-M } & \multicolumn{2}{c}{ CSI } & \multicolumn{2}{c}{ Gingivitis } & \multicolumn{2}{c}{ pH saliva } \\
\cline { 3 - 12 } & & $\begin{array}{c}\text { Rendah Sedang } \\
(\leq \mathbf{2 0})\end{array}$ & $\begin{array}{c}\text { Tinggi } \\
(\mathbf{2 1 - 4 0 )}\end{array}$ & $\begin{array}{c}\text { Tidak } \\
\mathbf{( 4 1 - 6 0 )}\end{array}$ & parah & Parah & Ada & $\begin{array}{c}\text { Tidak } \\
\text { Ada }\end{array}$ & \multicolumn{2}{c}{ AsamSedangNormal } \\
\hline Protein & Kurang $(<32 \mathrm{~g})$ & 1 & 8 & 11 & 17 & 3 & 8 & 12 & 11 & 9 & 20 \\
& Cukup $(=32 \mathrm{~g})$ & 0 & 1 & 1 & 2 & 0 & 1 & 1 & 1 & 1 & 2 \\
& Lebih $(>32 \mathrm{~g})$ & 10 & 33 & 35 & 71 & 7 & 21 & 57 & 36 & 35 & 78 \\
\hline Lemak & Kurang $(<38 \mathrm{kkal})$ & 1 & 23 & 30 & 48 & 6 & 18 & 36 & 30 & 24 & 54 \\
& Cukup (=38 kkal) & 0 & 1 & 0 & 1 & 0 & 0 & 1 & 0 & 0 & 1 \\
& Lebih $(>38 \mathrm{kkal})$ & 10 & 18 & 17 & 41 & 4 & 12 & 33 & 18 & 21 & 45 \\
\hline
\end{tabular}

tein dan lemak dalam penelitian ini tidak ada hubungan dengan CSI dan gingivitis.

Pada penelitian ini terlihat ada hubungan antara asupan protein dengan PHP-M ( $p<0,05$; Tabel 4). Protein termasuk makanan yang nonkariogenik. Sumber nabati pada penelitian ini selain bersifat nonkariogenik juga memerlukan pengunyahan. Pengunyahan selain bersifat mengurangi pembentukan plak, juga merangsang produksi saliva, yang berefek mekanis pada rongga mulut. Jenis makanan jajanan yang kariogenik (coklat, permen dan sejenisnya) tidak mudah dibersihkan dan melekat pada permukaan gigi daripada jenis makanan yang lebih rendah kandungan karbohidratnya (bakso, mie dan sejenisnya), sehingga mempengaruhi terjadinya plak (14). Plak selalu terbentuk, meskipun seseorang tidak mengkonsumsi makanan, tetapi sifat plaknya akan berbeda. Plak bisa bersifat kariogenik, dapat pula nonkariogenik, tergantung jenis makanan yang dikonsumsi.

Protein merupakan sumber asam amino yang sangat diperlukan untuk perkembangan gigi, sintesis enzim dan hormon di dalam saliva yang berguna untuk pertahanan tubuh terhadap kuman kariogenik. Protein dapat menekan penurunan $\mathrm{pH}$ saliva sehingga mencegah kondisi asam dalam mulut (5). Dalam penelitian ini $\mathrm{pH}$ rata-rata 5,96. Derajat keasaman ini mendekati normal (basa). Diet Protein, dalam hal ini 119,95\% AKG (Tabel 3) akan menyebabkan kandungan urea dalam saliva tinggi, sehingga memberi efek sifat basa dan $\mathrm{pH}$ ini bukan merupakan $\mathrm{pH}$ kritis yang dapat menyebabkan terjadinya proses karies gigi, ataupun memperparah karies gigi yang sudah terjadi, karena yang diukur adalah $\mathrm{pH}$ saliva secara keseluruhan, yang merupakan produksi kelenjar saliva mayor, minor, cairan krevicular gingiva, dan komponen-komponen plak.

Pada penelitian ini menunjukkan ada hubungan negatif antara asupan lemak dengan PHP-M. Lesitin yang merupakan gugus basa dari fosfolipid dalam lemak mempunyai kemampuan untuk membentuk emulsi
TABEL 5. Hubungan asupan protein dan lemak dengan status kesehatan mulut

\begin{tabular}{lccc}
\hline Variabel & $\mathbf{x} \pm \mathbf{S D}$ & $\mathbf{r}$ & $\mathbf{p}$ \\
\hline Protein & $38,3920 \pm 7,0637$ & $-0,200$ & $0,046^{*}$ \\
PHP-M & $35,7100 \pm 7,0929$ & & \\
\hline Protein & $38,3920 \pm 7,0637$ & $-0,189$ & 0,060 \\
CSI & $2,6680 \pm 0,8924$ & & \\
\hline Protein & $38,3920 \pm 7,0637$ & 0,180 & 0,074 \\
Gingivitis & $1,7000 \pm 0,4610$ & & \\
\hline Protein & $38,3920 \pm 7,0637$ & 0,202 & $0,044^{*}$ \\
pH saliva & $5,9660 \pm 0,8923$ & & \\
\hline Lemak & $37,3910 \pm 8,2677$ & $-0,230$ & $0,021^{*}$ \\
PHP-M & $35,7100 \pm 7,0929$ & & \\
\hline Lemak & $37,3910 \pm 8,26767$ & $-0,190$ & 0,058 \\
CSI & $2,6680 \pm 0,8924$ & & \\
\hline Lemak & $37,3910 \pm 8,2677$ & 0,194 & 0,053 \\
Gingivitis & $1,7000 \pm 0,4610$ & & \\
\hline Lemak & $37,3910 \pm 8,2677$ & 0,221 & $0,027^{*}$ \\
pH saliva & $5,966 \pm 0,8924$ & & \\
\hline Keterangan: & & & \\
\hline
\end{tabular}

Keterangan:

* Signifikan $(p<0,05)$

(cairan yang mengandung minyak). Lesitin terdapat luas dalam makanan terutama pada kuning telur. Lemak melapisi permukaan email dengan substansi seperti minyak yang akan menyebabkan partikel makanan tidak mudah melekat pada permukaan gigi (5).

Aliran saliva akan membersihkan sisa makanan dari rongga mulut dan bersifat buffer serta menetralkan asam yang dibentuk (15). Di dalam rongga mulut, sisa makanan maupun bakteri sukar melekat pada bagian yang dilapisi oleh lemak, sehingga tidak terjadi atau ada hambatan proses metabolisme sisa makanan. Ini berarti terjadi hambatan dalam penurunan $\mathrm{pH}$ saliva.

Penelitian ini menunjukkan ada hubungan antara asupan lemak dengan $\mathrm{pH}$ saliva $(\mathrm{p}<0,05$; Tabel 5$)$. Ratarata asupan lemak pada subjek penelitian kurang dari angka kecukupan gizi yaitu 98,37\% AKG (Tabel 3), 
akan tetapi telur yang sering dikonsumsi subjek penelitian membantu menghambat keasaman saliva. Pengolahan zat putih telur menjadi basa yaitu amin dan ammonia merupakan mekanisme netralisasi yang diproduksi oleh saliva.

Penelitian ini terlihat bahwa tidak ada hubungan antara asupan protein dengan CSI ( $p>0,05$; Tabel 5). Meskipun karies gigi dapat terjadi segera setelah gigi erupsi, tetapi hal ini tidak dapat untuk memprediksi progresivitas karies, yang merupakan salah satu penanda keparahan karies. Subjek penelitian mungkin def-t nya tinggi, tetapi bila terdapat karies yang tidak dalam, atau permukaan yang karies sedikit, maka dapat mengakibatkan CSI rendah.

Dalam penelitian ini asupan protein sudah mencukupi angka kecukupan gizi yaitu $119 \%$ AKG (Tabel 3). Protein karies memerlukan waktu yang lama, karena dalam rongga mulut selain ada proses demineralisasi tetapi juga ada proses remineralisasi. Remineralisasi dapat terjadi karena sifat saliva yang selalu jenuh dengan mineral, juga dapat dari komponen makanan.

Penelitian ini menunjukkan bahwa tidak ada hubungan antara asupan protein dengan gingivitis ( $p>0,05$; Tabel 5 ). Gingivitis pada subjek penelitian berupa peradangan yang berlokasi terutama pada daerah gingivalmargin (pinggiran gingival yang tidak melekat pada bagian servikal gigi).

Asupan protein pada penelitian ini mencukupi angka kecukupan gizi yaitu 119,95 AKG (Tabel 3). Meskipun asupan protein cukup tetapi bentuk sediaan makanan yang disukai sering diberikan kepada subjek penelitian, diperkirakan kurang mendukung untuk kesehatan gingivanya. Bentuk makanan yang halus dan lunak tidak memerlukan pengunyahan yang kuat, sehingga daya pembersihnya rendah.

Makanan yang mengandung lemak, pada umumnya sedikit mengandung substrat kariogenik selain sebagai makan pengganti karbohidrat yang karioganik, lemak juga mempengaruhi kelarutan karbihidrat di dalam rongga mulut (16).

Pada penelitian ini menunjukkan tidak ada hubungan antara asupan lemak dengan CSI ( $p>0,05$; Tabel 5). Hal ini karena subjek penelitian mungkin def-t tinggi, tetapi bila dalam pemeriksaan karies yang ada tidak dalam, atau permukaan yang karies tinggi, maka CSI rendah.

Rata-rata asupan lemak pada penelitian ini kurang dari angka kecukupan gizi yaitu 98,37\% AKG (Tabel 3). Lemak merupakan nutrien yang sifatnya nonkariogenik, jadi dapat diperkirakan ikut berperan dalam penghambatan proses karies gigi dalam hal ini.

Saliva berfungsi sebagai antimikroba antara lain adanya kandungan lisosim yang membantu melindungi permukaan gigi. Perlindungan ini ditunjang dari gingival crevicular fluid yaitu cairan yang mengalir ke celah gingiva gingivitis pada subjek penelitian berupa peradangan yang terutama beralokasi pada daerah gingival margin (pinggiran gingiva yang tidak melekat pada bagian servikal gigi).

Pada penelitian ini menunjukkan tidak ada hubungan antara asupan lemak dengan gingivitis ( $p>0,05$; Tabel 5). Hal ini diperkirakan selain asupan lemak yang diberikan kepada subjek penelitian kurang mendukung kesehatan gingivanya, dapat juga karena proses pengolahan makanan yang kurang tepat.

Protein dan lemak merupakan makanan yang nonkariogenik. Protein secara sistemik berpengaruh terhadap saliva sehingga $\mathrm{pH}$ saliva ke arah basa. Efek lokal protein terutama sumber nabati sehingga menaikan $\mathrm{pH}$ saliva. Sisa protein tidak difermentasi, sehingga tidak menurunkan $\mathrm{pH}$ saliva. Lemak lebih ke arah efek lokal, sehingga sisa makanan tidak mudah menempel pada permukaan gigi, bakteri tidak memfermentasi sisa makanan dan bersifat hidrofob sehingga bersifat anti bakteri. Derajat keasaman saliva ke arah basa, hal ini berhubungan dengan plak yang tidak setebal $\mathrm{pH}$ saliva asam, sesuai dengan penelitian ini yaitu PHP-M sedang. Kedua hal ini ( $\mathrm{pH}$ saliva dan PHP-M) bukan merupakan keadaan yang kritis untuk terjadi atau berkembangnya karies, sehingga CSI tidak parah.

Gingivitis selalu dikaitkan dengan derajat kebersihan mulut (PHP-M), meskipun gingivitis terdapat dalam penelitian ini, tetapi bukan gingivitis yang parah karena kebersihan mulut dalam kategori yang sedang, apalagi anak-anak, gingiva yang cembung, gemuk, pendek dan bentuk gigi sulung yang pendek, tanpa undercut, disertai produksi saliva yang relative lebih banyak daripada dewasa sehingga self cleaning lebih baik. Semakin jelek kebersihan mulut maka semakin parah gingivitisnya.

\section{KESIMPULAN DAN SARAN}

Penelitian mengenai hubungan antara asupan protein dan lemak dengan status kesehatan mulut pada anak usia prasekolah di Kecamatan Jetis Kabupaten Bantul Daerah Istimewa Yogyakarta, dapat disimpulkan sebagai berikut :

1. Ada hubungan antara asupan protein dengan status kesehatan mulut (yaitu derajat kebersihan mulut dan derajat keasaman saliva).

2. Tidak ada hubungan antara asupan protein dengan status kesehatan mulut (yaitu tingkat keparahan karies dan gingivitis).

3. Ada hubungan antara asupan lemak dengan status kesehatan mulut (yaitu derajat kebersihan mulut dan derajat keasaman saliva). 
4. Tidak ada hubungan antara asupan lemak dengan status kesehatan mulut (yaitu tingkat keparahan karies dan gingivitis).

Diperlukan penyuluhan tentang pola makan terhadap status kesehatan mulut, agar resiko terjadinya karies gigi dan penyakit periodontal dapat dicegah sejak dini.

Diperlukan penelitian lanjutan yang lebih mendalam untuk melihat hubungan protein dan lemak dengan status kesehatan mulut. Banyaknya jenis makanan saat ini, meskipun dengan jelas tidak termasuk makanan kariogenik, tetapi mengandung gula yang tidak tampak.

\section{RUJUKAN}

1. Supartinah Al. Peran Cariogram dalam Pencegahan Terjadinya Karies Baru padaAnak. Pidato Dies Natalis ke-40 FKG UGM; 2000; Yogyakarta, Indonesia.

2. Rinaldi BU, dan Iwa S. Status kesehatan gigi anak balita pada anak-anak prasekolah di kotamadya Yogyakarta. Buku Kumpulan Majalah IImiah Kongres Nasional XVI., Denpasar: Persatuan Dokter Gigi Indonesia; 1985. p. 45-50.

3. Kusuma P. Penyuluhan dan Pengobatan Gigi Anak TK Tunas Melati, Sidoarum, Godean, Yogyakarta. Laporan Pengabdian Masyarakat, LPM UGM; 1996.

4. Harini S. Pengendalian Diet Untuk Mencegah Karies Pada Anak. Jurnal Kedokteran Gigi UI 2000;7:156-61.

5. Heriandi Y. Konsumsi Makanan dan Resiko Karies pada Anak Prasekolah. Dental Journal 2001;34:477-80.

6. Blount RL, and Stokes, TF. A comparison of the $\mathrm{OHI}-\mathrm{S}$ and the PHP in an Oral Hygiene Program. J Dent Child 1986:53-6.

7. Koloway B, and Kailis DG. Caries, Gingivitis and Oral Hygiene in Urban and Rural Pre-school Children in Indonesia. Community Dent Oral Epidemiol 1992;(20):157-158.
8. Caranza FA. Clinical Periodontology. 7th Ed. Philadelphia: Saunders Company; 1990. p. 14-20, 96-101.

9. Departemen Kesehatan RI. Pedoman Penyelenggaraan Upaya Pelayanan Kesehatan Gigi di Puskesmas. Jakarta: Direktorat Kesehatan Gigi Depkes RI; 1995

10. Suwello IS. Karies Gigi pada Anak dengan Pelbagai Faktor Etiologi, Jakarta: EGC; 1992.

11. Sastroasmoro S. Dasar-dasar metodologi penelitian klinis. Jakarta: Sagung Seto; 2002.

12. Lemeshow S, Hosmer DW, Klar J, Lwangsa K. 1997. Besar Sampel dalam Penelitian Kesehatan. (Terjemahan) Pramono D. Yogyakarta: Gadjah Mada University Press; 1997.

13. Willet W. Nutritional Epidemiology, New York: Oxford University Press; 1990.

14. Sulistiandi W. Pengaruh Lingkungan Intra Oral dan Ekstra Oral terhadap Status Karies Gigi pada Anak Sekolah Dasar Kelas VI di Kecamatan I di Rayeuk kabupaten Aceh Timur tahun 1999. J. Ked. Gigi, UI. 2000;(7): 347-352.

15. Gunawan. Diet, Karies dan Kebersihan Sisa Makanan pada Gigi untuk Mengoptimalkan Perawatan Gigi Anak. Majalah Kedokteran gigi. Dental Journal Edisi Khusus Pertemuan IImiah Nasional 2003:42-45.

16. Petti, S., Tarsitani, G, Panfili, P, and Simonetti. Oral Hygiene, Sucrose Consumption and Dental Caries Prevalence in Adolescent Systemic Fluoride Nonusers. Community Dent Oral Epidemiol 1997;(25):334-336 